\title{
О ЖЕНЩИНАХ-ТЕРРОРИСТКАХ В ПРОЗЕ ЭМИГРАНТА РОМАНА ГУЛЯ
}

\author{
ON FEMALE TERRORISTS IN THE PROSE \\ OF THE EMIGRANT ROMAN GUL
}

\author{
JOANNA MIANOWSKA
}

\begin{abstract}
Aвstract. The article analyses the images of female terrorists in a novel of Roman Gul, a first-wave Russian emigrant. The members of the Socialist Revolutionary Party, including women, committed two well-known terrorist acts, i.e. the assassination of the Minister of the Interior Vyacheslav von Plehve and the murder of Grand Duke Sergey Alexandrovich.

Keywords: Female terrorists, terrorism, terrorist activities, the Socialist Revolutionary Party, revolutionary sympathies

Joanna Mianowska, Uniwersytet Kazimierza Wielkiego w Bydgoszczy, Bydgoszcz Polska,miano@wp.pl
\end{abstract}

ORCID ID: 0000-0002-5084-053X

В настоящее время слова „террор”, „террористки” и производные явно запугивают и ассоциируются с насилием, поджогами, взрывами или захватом заложников. Напомним, что понятия „терроризм” и „террорист" появились впервые во Франции еще в конце XVIII века, и связаны они были с якобинцами, при этом не обозначали ничего негативного [см. Тищенко 2008]. Однако уже во время Великой французской революции (1789) слово „терроризм” связано было с преступлением.

В России в XIX веке можно говорить о революционном терроризме как о массовом явлении, которое появилось после крестьянской реформы 1861 года. Убийство с помощью самодельной бомбы царя Александра II это лишь начало российского терроризма. Его пиками принято считать 70-80-е годы XIX века и 1901-1911 годы XX столетия [Будницкий 2000]. Напомним, что одним из ключевых моментов российского терроризма был выстрел Веры Засулич, которая ранила петербургского градоначальника Федора Трепова, но была оправдана и освобождена. Теракты народников, переход от пропаганды к террору, от анархизма к политической борьбе положили начало российскому террору XX века. В конце 1901 года была основана Боевая организация эсеров. Ее основа- 
телем и главой был Григорий Гершуни (1901-1903), после ареста которого организацию возглавлял провокатор Евно Фишелевич Азеф, тайный агент полиции, разоблаченный в 1908 году, а его заместителем и доверенным лицом стал Борис Савинков [Гейфман 1997: 78-83]. Устав партии был написан Михаилом Гоцом.

Эти соображения целесообразно ввести для лучшего понимания явления терроризма в прозе Романа Гуля, эмигранта первой волны русской эмиграции, известного историка и мемуариста. Хочется подчеркнуть, что в нашем исследовании не ставится вопрос о размахе и типах современного терроризма, на эти и другие, связанные с ними вопросы, должны ответить политологи и историки.

В Польше проза Гуля малоизвестна [см. Mianowska 2011], творческая биография писателя представлена в переведенном на польский язык лексиконе немца Вольфганга Казака, а также в словаре Глеба Струве и в новейших российских энциклопедиях, посвященных эмиграции [Kasack 1996: 209-210; Струве 1996: 304; Николюкин 1997, I: 147-149; Николюкин 2002, III: 178-189; Мухачев и др. 2006: 224-225; Мнухин и др. 2008, I: 443].

Гуль был участником сменовеховского движения. В годы Гражданской войны он сначала попадает в плен к Петлюре, затем немцы вывозят его в Германию. С 1920 года он проживает в Берлине, в 1933, после ареста и освобождения, эмигрирует в Париж. Во время немецкой оккупации живет на полулегальном положении. В 1950 году Гуль эмигрировал в США и после получения американского гражданства стал главным редактором „Нового журнала” и нью-йоркского отдела радиостанции „Свобода". В его биографии настораживает факт участия в сменовеховском движении, но в эмиграции Гуль становится яростным и непримиримым врагом СССР. Вместе с Добровольческой армией и белым генералом Лавром Корниловым Гуль участвует в легендарном „Ледяном походе" по югу России, описав увиденное и пройденное в романе Ледяной поход [Гуль 1990].

Гуль, попав в круговорот исторических событий XX века, стал свидетелем и жертвой немецкого нацизма и советского террора. Пережитое сформулировало интерес прозаика к ярким историческим личностям, свидетельством чего являются его очерки о Феликсе Дзержинском, Вячеславе Менжинском [Mianowska 2011]. Интерес свой Гуль проявил и к террористам Савинкову и Азефу [Гуль 1994]. Струве высоко оценивал мастерство автора романа Азеф [Струве 1996: 127]. При написании романа Азеф (сначала он назывался Генерал БО) Гуль пользовался книгой Савинкова Воспоминания террориста, изданной в 1909 году. Сам террорист Савинков был писателем и поэтом, написав Воспоминания 
террориста (1917-1918), повести Конъ бледный (1909) и Конъ вороной (1923) [см. Савинков 1990].

Чтобы понять позицию тех, кто террор возводил в принцип революционного движения, целесообразно обратиться к роману Гуля Азеф и сравнить его с Воспоминаниями террориста Савинкова, дворянина по происхождению, которого звали также „надломленной скрипкой Страдивариуса". Так называл Савинкова Михаил Гоц, „огонь и совесть” партии эсеров. Гуль в Азефе цитирует его стихи многократно [Гуль 1994: 125, 127 и др.]. Азеф начинается строками стихотворения Савинкова: „Глухо стукнет земля, сомкнется желтая глина, и не станет того господина, который называл себя я" [Гуль 1994: 5]. В некоторых местах Азефа Гуль пользуется Воспоминаниями террориста Савинкова, часто ничего не меняя в содержательном плане. Повторяются даже выражения, произносимые Азефом и другими героями Гуля: „работать в терроре”, „в боевом деле” и другие. В своей биографии Гуль пишет, что по его роману Генерал БО в 1937 году в русском театре в Париже была поставлена пьеса Азеф [см. Гуль 1986].

Интересен тот факт, что роман Гуля вышел впервые по-польски в переводе Халины Пилиховской еще в 1933 году: „ROMAN GUL. General BO. Powiesc. Przelozyla z rosyjskiego Halina Pilichowska, Towarzystwo Wydawnicze «Roj», Warszawa. 1933". Позже в предисловии к четвертому изданию романа Азеф писатель заявлял:

Не так давно знакомые американцы, побывавшие в Варшаве, рассказали мне, что мой роман „Генерал БО” в переводе Галины Пилиховской переиздан и сейчас продается в Польше. Выпустило его в 1958 году издательство „Książka i Wiedza”. Переиздание сделано без моего разрешения и без моего ведома [Гуль 1959].

Неудивительно, что в 50-е годы в Польше издательство могло переиздавать книгу без разрешения автора, ведь Гуль был белым эмигрантом, проживающим в этот период в США, и связь с ним была невозможна по известным причинам.

Книга Азеф это переработка романа Генерал БО. Под руководством заместителя Азефа Бориса Савинкова члены Боевой организации совершили два известных террористических акта: убийство министра внутренних дел Вячеслава Плеве (15 июля 1904 года) и убийство великого князя Сергея Александровича (4 февраля 1905 года).

Особое место в романе Гуля Азеф уделяется женщинам, „работавшим в терроре". Вообще среди террористов женщин было немало. Это и Мария Спиридонова, смертельно ранившая губернского советника Гавриила Луженовского, подавлявшего крестьянские восстания в Тамбовской губернии; и Софья Перовская, казненная за политическое преступле- 
ние; и Зинаида Коноплянникова, застрелившая командира семеновского полка генерала Георгия Мина; и Екатерина Измайлович; и Наталья Климова и многие другие. В книге Гуля появляется также фигура „бабушки русской революции" Катерины Брешковской, каторжанки, пытающейся вербовать в партию эсеров новые силы. Гуль рисует ее прошлое, а также отрицательное отношение Брешковской к марксистской программе. Например, в разговоре с Савинковым Брешковская признается, что марксисты, и среди них Ленин, а также Крупская „не нашего поля ягоды” [Гуль 1994: 22]. Брешковская о Ленине и Крупской далее высказывает такое мнение: „Уж не люблю, грешница, я этих механиков” [Гуль 1994: 22]. У Гуля можно узнать прошлое „знаменитой бабушки революции", которая после двух каторг и семилетнего поселения решает вновь „работать в терроре”. Прозаик отмечает: „...стара уж бабушка, пересидевшие кости подняла с трудом" [Гуль 1994: 21]. А у Савинкова с „бабушкой” Брешковской связана одна мечта: „Хочу террора... настоящего, народовольческого" [Гуль 1994: 21].

В романе Гуля вырисовывается образ другой женщины-террористки Доры Бриллиант, носившей черное шелковое платье - „классический мундир террористок" [Гуль 1994: 89]. О себе Дора Бриллиант говорит:

Мой отец купец, жили хорошо, были средства. Но родители до исступления ортодоксальные евреи, это помешало образованию, я ушла из дома, пыталась пробиваться, ну а потом захватило революционное движение и на всю жизнь

и далее:

на меня неизгладимое впечатление произвели два человека Брешковская и Гершуни. После них я пошла в революцию, и революция стала моей жизнью [Гуль 1994: 91].

Гуль отмечает в Доре-террористке „смешанность грусти и решимости” и главное: „Он (Савинков - И.М.) знал, хрупкая, болезненно красивая Дора пойдет на любой террористический акт" [Гуль 1994: 90]. Грусть Доры, отмечаемая в Азефе, -„,тысячелетняя еврейская грусть" [Гуль 1994: 89]. Юрий Степанов справедливо подчеркивает, что явление грусти и печали ассоциируются не только с Россией и русскими. Он рассматривает несколько элементов внутренней формы этого концепта [Степанов 2001: 898-902]. Однако определение „еврейской грусти” у Гуля связано с духовным одиночеством Доры Бриллиант. Отметим, что делая свой выбор относительно „работы в терроре”, Дора помнила об организованном министром внутренних дел Плеве погроме евреев в Кишиневе (6-7 апреля 1902), ставшем национальной трагедией. Далее вспыхнули 
погромы в разных местностях России [см. Портнова 2002: 9-10]. Жестокий погром евреев в Белостоке, житомирский погром и даже „ритуальные" процессы доказывали, что в революции 1905 года участвуют евреи, а основное население российской империи предано ей и само расправляется с революционерами.

О Доре Бриллиант с подробностями повествует и Борис Савинков (в эмиграции по поручению организации она выполняла роль содержанки Савинкова, они вместе жили на конспиративной квартире). Савинков пишет о Доре Бриллиант подробнее и беспристрастно, оперирует фактами, из которых можно узнать всю ее биографию, этапы жизни, участие в деле Плеве, закючение в Петропавловской крепости, наконец, психическое заболевание и однозначную оценку автора: „В ее лице боевая организация лишилась одной из самых крупных женщин террора" [Савинков 1990: 163]. У Савинкова находятся сведения о ее рождении, образовании (херсонская гимназия и акушерские курсы при юрьевском университете), приеме в партию эсеров и работе в киевском комитете [Савинков 1990: 163]. Гуль заимствует у Савинкова подлинные факты из жизни Доры, расширяя их своими соображениями и диалогами и стараясь придать им не только фактологию, но и романтику. В диалоге Азефа и Савинкова у Гуля Великий Провокатор говорит: „Глупая романтика... мужчина, женщина - одинаковые члены партии, но для твоего спокойствия я отвожу Дору" [Гуль 1994: 107]. Гуль приводит в Азефе стихи Савинкова Когда принесут мой гроб, посвященные этой террористке [Гуль 1994: 101].

Автор Азефа раскрывает также образ Прасковьи Семеновны Ивановской, старой народовольки, исполнявшей роль тетушки и кухарки. В этой фигуре подчеркивается теплота и громкий, раскатистый смех: „как смеются добрые люди” [Гуль 1994: 92]. Когда в квартиру, которую снимали Савинков и Дора, приходит на явку один из террористов, Сазонов, Ивановская чувствует родственность с ним: „Словно встали из гробов Желябов, Михайлов. Сила, ясность. Ни анализов, ни сомнений, ни колебаний. Воля, знающая цель" [Гуль 1994: 92]. В Варшаве Ивановская как член БО была уже не кухаркой, а барыней, одетой в элегантное платье, в соломенную шляпку, ходила с зонтиком. Ей при встрече Савинков признается: „Рубить березу, убить животное проще, а человека убить трудно. В этом есть что-то непонятное... метафизическое" [Гуль 1994: 115].

Савинков более подробно и фактографически повествует о женщинах, проявляющих свои революционные симпатии. Среди них Татьяна Леонтьевна, не только по внешности напоминающая светскую барышню, которая ездила на балы, рассчитывая приобрести нужные 
для эсеров знакомства и сведения. Автор Воспоминаний террориста подчеркивает ее сосредоточенную силу воли (как у Доры Бриллиант) и в этой связи констатирует: „Она (Татьяна Леонтьевна - И.М.) участвовала в терроре... с радостным сознанием большой и светлой жертвы” [Савинков 1990: 109].

У Гуля в Азефе многие женщины-террористки не названы, ибо автор сосредоточился на представлении образов женщин, непосредственно связанных с актами террора. Зато у Савинкова таких характеристик много. В организацию БО, которую он формировал, вступила Маня Школьник, о которой в Воспоминаниях террориста сказано: „В каждом ее слове и в каждом жесте сквозила фанатическая преданность революции” и далее: „Она (Маня Школьник - И. М.) показалась мне агитатором по призванию, но и сила ее преданности террору не подлежала сомнению” [Савинков 1990: 110]. Эта террористка у Савинкова представлена гораздо ярче, обрисован также ее женский характер, слезы на глазах, сильная жестикуляция. Бомбою Школьник был ранен, по Савинкову, губернатор Хвостов в Чернигове в 1906 году, а террористка получила наказание 20 лет каторжных работ [Савинков 1990: 129]. Гуль же, создавая художественное произведение Азеф, стремится придать ему лирический настрой, многое заимствует у Савинкова, однако главное у писателя это жизнь и деяния „Великого Провокатора” Азефа и его заместителя в „работе по террору” Савинкова.

О Вере Савинковой, жене террориста, лишь опосредованно связанной с террором, также много рассказано в Азефе. Вера Глебовна отдавала себе отчет в том, что Савинков ее по-своему любит, и ожидала от него больше ласки. Однако ее муж, только начинающий борьбу, на вопрос своей жены: „И я пойду с тобой. Разве не было женщин в революции?” ответил: „Женщины в революции никого не любили кроме революции” [Гуль 1994: 11]. После ссылки Бориса в Вологду, Вера приехала к нему и рассказала о родившейся дочке Танюшке, пожалев тех женщин, которые не рожали (она назвала среди них Перовскую). Веру Савинкову „бабушка" Брешковская называет „плохой конспираторшей”, не знающей правил поведения на каторге (каторжанке Брешковской нельзя было ночевать у поднадзорного Савинкова, о чем жена террориста не знала). Судьба жены Савинкова предопределена - жизнь в страхе и одиночестве. Савинков еще встретится со своей женой и детьми во Франции. Гуль отразил в Азефе пребывание всей семьи в Париже в квартире на рю де ля Фонтен [Гуль 1994: 256-262]. Но жена террориста знала, что даже увлечение мужа замыслом написания романа не лишит его скуки и тоски, рождающейся у человека, убивающего людей. Гуль в этой связи скажет: 
Савинков ощущал... беспокойство. [...] ...ОН думал, что тема убийства уже сильно использована Достоевским, но разница была в том, что Достоевский никогда сам никого не убивал, а Савинков убивал, и Савинкову казалось, что Достоевский не знал многого, что так хорошо знал Савинков [Гуль 1994: 256].

Кроме женщин-террористок, связанных с Савинковым, в романе Азеф упоминаются также его мать и жена Вера. Они не „работали в терроре", но любили его, стремились понять его сложную и яркую фигуру. Жене Савинкова Гуль уделяет большое внимание из-за самой личности террориста, считавшего, что даже на Лубянке он встретил „убежденных и честных революционеров, тех, к которым привык с юных лет" [Давыдов 1990: 17]. Отношения Савинкова и его жены Веры у Гуля представлены достаточно подробно и правдиво. Савинков не был способен организовать и вести спокойную супружескую жизнь. Его жена, Вера, хотела искренности и любви мужа. Она любила его стихи, но не знала, что Савинкову была нужна слава террориста и художника [Гуль 1994: 256-262]. Гуль приводит в Азефе такие слова Савинкова: „Я не хочу быть рабом, даже рабом свободным. Вся моя жизнь - борьба. Я не могу не бороться. Но во имя чего я борюсь - я не знаю. Я так хочу. И я пью вино цельное" [Гуль 1994: 307]. Стоит отметить, что жена Савинкова, считала, что „ошиблась своей жизнью”, и винила революцию и товарищей своего мужа в том, что они разбили ее счастье [Гуль 1994: 262]. В террористки она никак не годилась, зато жаждала от Савинкова часть его души и внутреннего мира. Они расстались, так и не поняв друг друга.

У Гуля появляются еще многие имена и краткие сюжеты, связанные с женщинами-террористками. К примеру, Саша Севастьянова, Рашель Лурье и Валентина Попова, работавшие в динамитной мастерской, в которой

...на двух столах стояли спиртовки, примусы, лежали медные молотки, напильники, ножницы для жести, пипетки, стеклянные трубки, наждачная бумага, в флаконах аккуратно, как в аптеке, была серная кислота. В углу - запасы динамита. И рядом, внутри выложенные парафиновой бумагой... оболочки снарядов [Гуль 1994: 223].

Валентина Попова была беременна, однако она не хотела прерывать своей террористической деятельности, несмотря на резоны Савинкова: „.... слуучае вашей гибели вы убьете живого ребенка. Кроме того, можете ослабеть, не совладать. Ведь придется трудно". Однако Попова настаивает на своем: „Вы обижаете меня как члена БО. Я говорю, что способна на работу" [Гуль 1994: 224].

В романе Гуля к Борису Савинкову, узнику одиночной камеры севастопольской гауптвахты, приходит на свидание мать Софья Алексан- 
дровна Савинкова, и на ее резкий плач и крик сын-террорист ответил: „Мама, не плачь, наши матери на плачут” [Гуль 1994: 233]. Мать Савинкова верила в помилование своего сына, хотя выходила после свидания с ним с лицом, смоченным слезами. Она и не предполагала, что скоро состоится удачный побег сына. В Воспоминаниях террориста Савинкова появляется запись о матери другого террориста Янека Каляева. Этот яркий революционер, хотя и родился от польки и вырос в Варшаве, от отца перенял любовь к русскому народу.

Гуль заимствует от Савинкова подробности биографий женщин-террористок, о некоторых из них прозаик ничего не пишет. У Савинкова, например, ярко обрисован образ Марии Беневской, верующей христианки, не раставшейся с евангелием, которая „каким-то неведомым и сложным путем пришла к утверждению насилия и к необходимости личного участия в терроре" [Савинков 1990: 170]. Внеся в жизнь народовольцев-террористов „христианскую незлобивость и деятельную любовь", Беневская обнаружила также мучительные нравственные запросы. Гуль лишь называет имена некоторых террористок, не вдаваясь в подробности и детали их жизни и судьбы. У него выделяется первый план женщин-террористок, явно связанных с покушениями на министра Вячеслава Плеве и великого князя Сергея Александровича, и второй план, состоящий из помощниц, которые сами участия в покушениях не принимали, однако своими деяниями доказывали, что верят в террор, часто ожидая случая принять активное участие в нем. Рашель Лурье, во многом напоминавшая Дору Бриллиант, считала своим долгом участвовать в терроре. Савинков отмечает, однако, ее глубокие внутренние и душевные переживания после попытки покушения на генерала Дубасова. Типичная женская психика сводилась к вопросу: а если Дубасов поедет с женой? [Савинков 1990: 178-179]. Желающих „работать в терроре” женщин было много, однако их труд состоял не только в самих покушениях. Самым трудным и неприятным делом было систематическое наблюдение за жертвой, они часто выполняли „черную” работу террористического дела: поездки, доставка динамита, получение сведений. Женщины были гораздо слабее мужчин и, случалось, что при работе с самодельной бомбой погибали от взрыва, как, например, Мария („Генриетта”) Беневская [Савинков 1990: 212].

Участие женщин в террористических актах у Романа Гуля - это литературное свидетельство свершившейся истории в конце XIX и начале XX веков. В романе много документального, но много и личного. Сравнивая мастерство Гуля и Савинкова, стоит отметить дар описания у романиста Гуля. О женщинах-террористках он пишет занимательно, живо и правдиво, остросюжетно, при том что главным героем является заглавный 
Азеф. Гуль в своем романе цитирует такое стихотворение Савинкова, посвященное Азефу:

Он дернул меня за рукав:

Скажи, ты веришь?

Я пошел впереди, помолчав,

А он, лохматый:

Ты лицемеришь!

А он, рогатый:

Ты лгать умеешь!

А он, хвостатый:

Молиться смеешь!

А он, смердящий:

В святые метишь!

А он, гремящий:

Ты мне ответишь!

На улице зажигались поздние фонари,

Нависали серые крыши.

Я пошел тише.

И вдруг услышал:

Умри!

[Гуль 1994: 296-297]

В романе Гуля провокатор Азеф уничтожил Савинкова, а представленные женщины-террористки, даже участвуя в непосредственных действиях, были лишь полезными помощницами по делу террора.

Сегодня терроризм - мужской или женский - это опасное явление мирового масштаба. Еще в начале XIX века Михаил Лермонтов пророчески предвидел:

Настанет год. России черный год

Когда царей корона упадет

Забудет чернь к ним прежнюю любовь

И пищей многих будет смерть и кровь

Когда детей, когда невинных жен

Низвергнутый не защитит Закон

[См.: Давыдов 1990: 10-11]

\section{Библиография}

Будницкий О. 2000. Терроризм в российском освободительном движении: идеология, этика, психология (вторая половина 19 - начало 20 века), Москва: Российская политическая энциклопедия.

Гейфман А. 1997. Революиионный террор в России, 1894-1917, пер. с англ. Е. Дорман, Москва: КРОН-ПРЕСС. 
Гуль Р. 1959. Азеф, Нью-Йорк: Мост, электронный ресурс: http://www.classic-book. $\mathrm{ru} / \mathrm{lib} / \mathrm{al} /$ book/866 (доступ 1.12.2017).

Гуль Р. 1986. Моя биография, „Новый журнал”, № 164, с. 14-82, электронный ресурс: http:/ / www.nnre.ru/istorija/moja_biografija/p1.php (доступ 1.12.2017).

Гуль Р. 1990. Ледяной поход, Москва: Молодая Гвардия.

Гуль Р. 1994. Азеф, Москва: Редакция журнала „Семья и школа”.

Давыдов Ю. 1990. Савинков Борис Викторович, он же В. Ропшин. Беглые заметки вместо академического предисловия, [в:] Б. Савинков, Избранное, Москва: Политиздат.

Мнухин Л. (ред.) 2008. Российское зарубежье во Франиии 1919-2000. Биографический словарь 8 трех томах, т. I, Москва: Дом-музей Марины Цветаевой.

Мухачев Ю. (гл. ред.) 2006. Литературное зарубежье России. Энциклопедический справочник под общей ред. Е. П. Челышева и А. Я. Дегтярева, Москва: Парад.

Николюкин А. (гл. ред.) 1997. Литературная энциклопедия русского зарубежья 1918-1940. ८ 4 томах, т. I: Писатели русского зарубежья, Москва: РОССПЭН.

Николюкин А. (гл. ред.) 2002. Литературная энциклопедия русского зарубежья 1918-1940. В 4 томах, т. III: Книги, Москва: РОССПЭН.

Портнова Н. (сост.) 2002. Быть евреем в России... Материалы по истории русского еврейства, 1900-1917 годы. Иерусалим: Принтив Пресс.

Савинков Б. 1990, Избранное, Москва: Политиздат.

Степанов Ю. 2001. Константы: словарь русской культуры, Москва: Академический проект.

Струве Г. 1996. Русская литература в изгнании. Краткий биографический словарь русского зарубежья, Париж-Москва: Русский путь.

Тищенко Н. 2008. Классный час „Терроризм - угроза обществу”, электронный ресурс: http:/ / открытыйурок.рф/статьи/511722/ (доступ 1.12.2017).

Kasack W. 1996. Leksykon literatury rosyjskiej XX wieku od poczatku stulecia do roku 1996, przekład, oprac., bibliografia polska i indeks osób B. Kodzis, Wrocław: Wydawnictwo Ossolineum.

Mianowska J. 2011. Вершители красного террора - Ф. Дзержинский и В. Менжинский В очерках Романа Гуля, „Acta Polono-Ruthenica”, № XVI. 